\title{
Crop Vulnerability: Carya
}

\author{
L.J. Grauke ${ }^{1}$
}

USDA-ARS Pecan Breeding and Genetics, 10200 FM 50, Somerville, TX 77879

\section{Bruce W. Wood \\ USDA-ARS Southeastern Fruit and Tree Nut Research Laboratory, 21 Dunbar Road, Byron, GA 31008 \\ Marvin K. Harris \\ Department of Entomology (Professor Emeritus), Texas A\&M University, College Station, TX 77843}

Additional index words. Carya illinoinensis, germplasm, diversity, breeding, repository, characterization

Abstract. Long-established native tree populations reflect local adaptations. Representation of diverse populations in accessible ex situ collections that link information on phenotypic expression to information on spatial and temporal origination is the most efficient means of preserving and exploring genetic diversity, which is the foundation of breeding and crop improvement. Throughout North America, sympatric Carya species sharing the same ploidy level tend to hybridize, permitting gene flow that contributes to regional diversity and adaptation. The topographic isolation of many fragmented populations, some of which are small, places native Carya populations of United States, Mexico, and Asia in a vulnerable position and justifies systematic collection and characterization. The characterization of indigenous Mexican pecan and other Carya populations will facilitate use for rootstocks and scion breeding and will contribute to pecan culture. The Asian species, as a group, are not only geographically isolated from North American species, but also occur in disjunct, fragmented populations isolated from other Asian species. Section Sinocarya includes the members of the genus most vulnerable to genetic loss. With all species, recognition of utility based on characterization of ex situ collections may contribute to the establishment of in situ reserves. Global Carya genetic resources should be cooperatively collected, maintained, characterized, and developed. The integration of crop wild relatives into characterization and breeding efforts represents a challenging opportunity for both domestic and international cooperation. Genomic tools used on the accessible collections of the National Collection of Genetic Resources for Pecans and Hickories (NCGR-Carya) offer great potential to elucidate genetic adaptation in relation to geographic distribution. The greatest progress will be made by integrating the disciplines of genetics, botany, pathology, entomology, ecology, and horticulture into internationally cooperative efforts. International germplasm exchange is becoming increasingly complicated by a combination of protectionist policies and legitimate phytosanitary concerns. Cooperative international evaluation of in situ autochthonous germplasm provides a valuable safeguard to unintended pathogen exchange associated with certain forms of germplasm distribution, while enabling beneficial communal exploration and directed exchange. This is threatened by the "proprietary" focus on intellectual property. The greatest risk to the productive development of the pecan industry might well be a myopic focus on pecan production through the lens of past practice. The greatest limitation to pecan culture in the western United States is reduced water quantity and quality; in the eastern United States the challenge is disease susceptibility; and insufficient cold hardiness in the northern United States. The greatest benefit for the entire industry might be achieved by tree size reduction through both improved rootstocks and scions, which will improve both nut production and tree management, impacting all areas of culture. This achievement will likely necessitate incorporation of crop wild relatives in breeding, broad cooperation in the testing leading to selection, and development of improved methods linking phenotypic expression to genomic characterization. The development of a database to appropriately house information available to a diverse research community will facilitate cooperative research. The acquisition of funds to pursue development of those tools will require the support of the pecan industry, which in the United States, is regionally fragmented and focused on marketing rather than crop development.

\section{Introduction to the crop}

\section{Biological features}

Pecan [Carya illinoinensis (Wangenh.) $\mathrm{K}$. $\mathrm{Koch}]$ is a tree species autochthonous (native) to North America (Fig. 1). It is the most economically valuable and agriculturally significant member of Carya. At maturity, pecan is a large, long-lived, monoecious, polymorphic, anemophilous, and deciduous tree. The nut (seed) has hypogeal germination and forms a dominate taproot with abundant lateral roots. Leaves are odd-pinnately compound with 11-17 leaflets, borne in alternate arrangement, with reduction in leaflet number, size, and pubescence as the tree matures Seedlings have long juvenility (5-12 years) and bear imperfect flowers at different locations on the tree. Male and female flowers mature at different times (dichogamy). Male flowers are borne on staminate catkins in fascicles of three, with catkin groups formed on opposite sides of each vegetative bud, sometimes with a second pair above, borne opposite each other, at $90^{\circ}$ to the first. The catkins are borne at the base of the current season's growth or from more distal buds of the previous season whose vegetative axis aborts after pollen shed. This pattern of catkin formation is characteristic of all members of section Apocarya, but is distinct from the other sections of the genus (Figs. 2-4). Pollen is produced in very large quantities and is carried by wind. Pistillate flowers are borne on fewflowered (1-9) terminal spikes. Individual trees whose catkins shed pollen before pistillate flower receptivity are termed "protandrous" or "first male." Individual trees whose female flowers reach receptivity before pollen shed are termed "protogynous" or "first female." As a population, trees are heterodichogamous, with mixed periods of bloom enabling cross pollination and outcrossing (Thompson and Romberg, 1985). This reproductive system facilitates heterozygosity in individuals and populations, and is accompanied by inbreeding depression. The fruit of pecan is a nut enclosed in a dehiscent husk that splits along more or less winged sutures to release the hard-shelled nuts. Nuts are tan to brown, mottled with black stripes at the apex and spots at the base. Shells are relatively thin as compared with most hickories, and protect the edible kernels, which are rich in mono- and polyunsaturated fats. Young pecan trees are slow to bear fruit, but increase in fruit production with age and size. Mature trees tend to be large and long lived, producing crops that alternate with regional synchrony in a roughly alternating manner with occasional masting (mass seeding) (Chung et al., 1995).

\section{Ecogeographical distribution}

Native stands of pecan are distributed primarily in well-drained soils of the Mississippi River and its tributaries from northern Illinois and southeastern Iowa south to the Gulf Coast of Louisiana and west to the Edwards Plateau of Texas in the United States (Fig. 1). Isolated populations occur as far east as southwestern Ohio and central Alabama, and as far west as Chihuahua, Mexico. Pecan has the westernmost distribution of any of the Carya species.

Hybridity in sympatric species of Carya sharing the same ploidy level is evident in the abundance of known hybrids (Table 1) and has recently been examined using molecular markers (Grauke and Mendoza-Herrera, 2012). Distribution maps are provided here by section and ploidy to aid in visualizing 

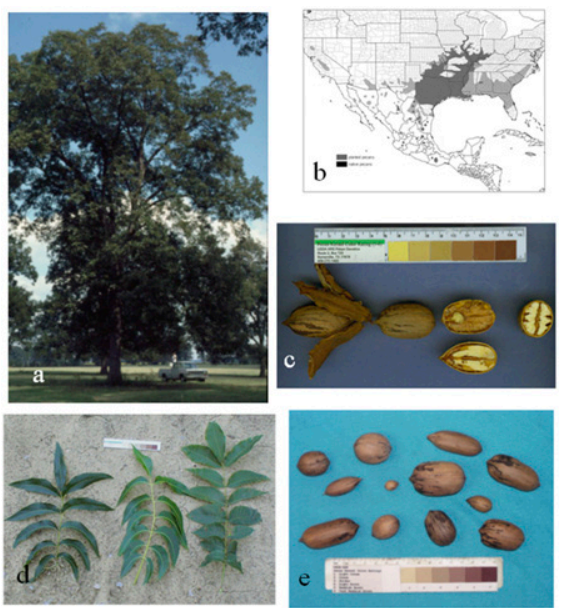

Fig. 1. (A) Carya illinoinensis (Wangenh.) K. Koch indigenous pecan tree, Red River Valley, TX. (B) Native distribution of species, and area of culture in North America. (C) 'Pawnee' nuts in husk, in shell, longitudinal, and cross sections. (D) Diversity in shape and size of adult phase leaves ['Upton' (BW 105-21); 'Aggie' (BW 104-30); 'Hadu 3' (BW 104-35)]. (E) Diversity in pecan nut size and shape.

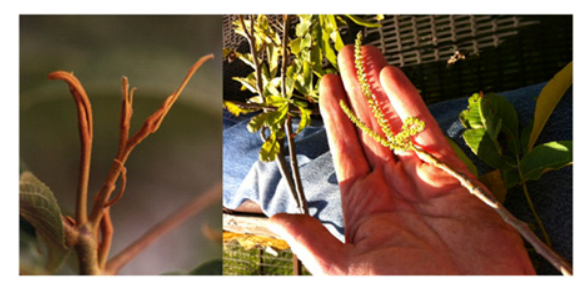

Fig. 2. Naked terminal buds (L) and single, 3-fascicled catkins (R) of Sinocarya (Carya cathayensis).

potential gene flow among North American Carya species (Figs. 5-7). Known distributions of Asian Carya species are more fragmented, with no species overlap (Fig. 8).

\section{Plant breeding and its products}

The primary commercial crop is pecan nuts, an increasingly global commodity. Pecan is the only Carya species that has benefited from significant breeding and selection. Most attention has been focused on scion breeding and selection. Openpollinated seed stocks are used to grow rootstocks, which vary by region. In addition, nuts of Carya ovata and Carya laciniosa are harvested from wild trees and consumed locally. In China, nuts of local native hickories [mixtures of Carya cathayensis and

Received for publication 1 Oct. 2015. Accepted for publication 12 Feb. 2016.

Mention of a trademark, proprietary product, or vendor does not constitute a guarantee or warranty of the product by the U.S. Department of Agriculture and does not imply its approval to the exclusion of other products or vendors that also may be suitable.

${ }^{1}$ Corresponding author. E-mail: 1j.grauke@ars. usda.gov.

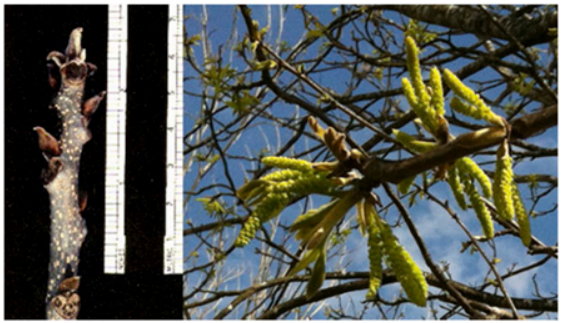

Fig. 3. Valvate terminal buds (L) and paired, opposite 3-fascicled catkins (R) of Apocarya (Carya illinoinensis). Catkins are borne at the base of the current season's growth as well as from buds lower on the shoot in which the vegetative apex aborts.

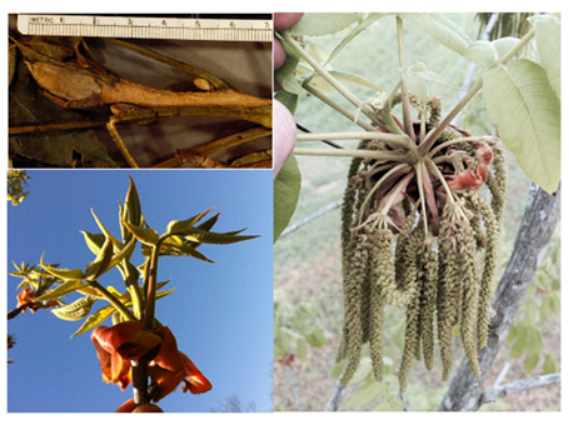

Fig. 4. Imbricate terminal buds (upper L) that swell greatly at growth initiation (lower L), and 3-fascicled catkins borne in axils of bud scales (R) in Carya (Carya laciniosa). Catkins are borne at the base of the current season's growth.

Carya dabieshanensis (Liu and Li, 1984)] are collected from natural stands and marketed primarily in China.

\section{Primary crop products and their value (farm gate)}

Commercial U.S. pecan production is divided into two major categories: "Native/ Seedling" and "Improved." "Native" pecans are ungrafted trees growing in natural, regenerating stands that were not established by humans. Native pecans represent the original forest, may hold the key to understanding climatic and edaphic adaptation, and are the genetic foundations for crop improvement. They also constitute large acreages producing relatively low yields of often poor-quality nuts. "Seedling" pecans are ungrafted trees grown from nuts that have been introduced and are therefore evidence of some level of selection. "Improved" pecans are selected cultivars grafted onto seedling rootstocks. Highest yields are achieved in orchards of 'Improved' pecans, with around $2000 \mathrm{~kg} / \mathrm{ha} /$ year being realized as the statewide average in some western states where all production is solely from improved plantings. By contrast, states with large numbers of native pecans, such as Texas, have low production per unit area. This is due to lower yields produced by natives $(<500 \mathrm{~kg} / \mathrm{ha} / \mathrm{year})$, and because many native pecans are not harvested annually (Ares et al., 2006). Highest prices are obtained for well-managed, improved pecans, whereas nuts from unmanaged improved cultivars may be sold at reduced prices as "Seedling" nuts. Production is erratic, with years of low production (but high kernel quality) often followed by very heavy crops (but low kernel quality). Farm gate price per pound tends to alternate in opposition to yield, with heavy crop years generally bringing low prices. In the 4 years between 2011 and 2014, total U.S. pecan production averaged 125.2 million $\mathrm{kg}$ per year (276 million lbs) with a mean annual farm gate value of 525 million dollars. Production from improved pecans was relatively flat during the 1990 s, but has recently increased due to substantial increases in crop value (Fig. 9). Increased exports to Asian markets have contributed to the strong prices received and to increased planting in recent years, which should result in increased future production. U.S. exports to China increased dramatically beginning in 2007. Before that year, the peak export to China had been almost 6000 $t$ in 2006 . Since the 2007 crop year, exports to China have not dropped below 20,000 t and in crop year 2012 exceeded 45,000 t (Zedan, 2015a). National area of bearing and nonbearing improved pecan orchards increased from 124,900 to 131,560 ha (an increase of 6660 ha or $5 \%$ ) between the 2007 and 2012 agricultural census (NASS, 2012). Production from native/seedling pecans has continued to decrease since the 1970s (Fig. 10). National land area of bearing and nonbearing native/seedling pecan trees decreased from 110,550 to 88,382 ha (a reduction of 22,168 ha, or $20 \%$ ) between the 2007 and 2012 agricultural census (NASS, 2012). If those figures are trustworthy, that is an alarming rate of loss in native area and should increase the motivation to characterize remnant stands of old native trees across the range.

\section{Domestic and international crop production}

United States (regional geography). Georgia produces the largest percent of the U.S. improved crop. Most production comes from mature orchards in the southern part of the state concentrated near the city of Albany. New acreage in middle Georgia, especially on the Fort Valley Plateau, is being planted to more recently developed cultivars of pecans, while older orchards in southern Georgia are being renovated to new cultivars (Wise, 2010). New Mexico is the second leading state in improved pecan production. Most New Mexico production comes from the Mesilla River Valley in Dona Ana County. This production is primarily from 'Western' and 'Wichita', with new plantings incorporating 'Pawnee' and other more recent releases. Oklahoma is the center of native pecan production, followed by Texas. During the early decades of the 20th century, native production exceeded improved production. Following World War II, improved production increased sharply and overtook native production during the 1960s. Increased planting of soybeans in Louisiana and Arkansas in the 1970s resulted in the destruction of thousands of hectares of native pecans (Grauke et al., 1995), beginning 
Table 1. Taxa recognized as species by the National Collection of Genetic Resources for Pecans and Hickories, listed alphabetically within section.

Section Sinocarya

1. Carya cathayensis Sarg. Chinese hickory ${ }^{z}$ (probably includes Carya dabieshanensis)

2. Carya hunanensis Cheng and R.H. Chang-Hunan hickory ${ }^{2}$

3. Carya kweichowensis Kuang and Lu-Guizhou hickory ${ }^{z}$

4. Carya tonkinensis Lecomte-Viet Nam hickory ${ }^{\mathrm{z}}$

5. Carya poilanei (A. Chev.) J. Leroy-Poilane's hickory ${ }^{2}$

Section Apocarya

6. Carya aquatica (F. Michx.) Nutt.-Water hickory

7. Carya cordiformis (Wangenh.) K. Koch-Bitternut hickory

8. Carya illinoinensis (Wangenh.) K. Koch-Pecan

9. Carya palmeri Manning-Mexican hickory

Section Carya

10. Carya floridana Sarg.-Scrub hickory

11. Carya glabra (Mill.) Sweet-Pignut hickory [includes Carya ovalis (Wangenh.) Sarg.-Red hickory]

12. Carya laciniosa (F. Michx.) Loudon-Shellbark hickory

13. Carya myristiciformis (F. Michx.) Nutt.-Nutmeg hickory

14. Carya ovata (Mill.) K. Koch-Shagbark hickory [includes Carya carolinae septentrionalis (Ashe) Engl. \& Graebn.-Southern shagbark hickory]

15. Carya pallida (Ashe) Engl. \& Graebn.-Sand hickory

16. Carya texana Buckley-Black hickory

17. Carya tomentosa (Poir.) Nutt.-Mockernut hickory

Interspecific hybrids

1. Carya $\times$ brownii $($ C. cordiformis $\times$ C. illinoinensis $)$ Sarg.

2. Carya $\times$ collina $(C$. texana $\times$ C. tomentosa) Laughlin

3. Carya $\times$ demareei $(C$. cordiformis $\times$ C. ovalis) Palmer

4. Carya $\times$ dunbarii $(C$. laciniosa $\times$ C. ovata $)$ Sarg.

5. Carya $\times$ laneyi $(C$. cordiformis $\times$ C. ovata $)$ Sarg.

6. Carya $\times$ lecontei $($ C. aquatica $\times$ C. illinoinensis $)$ Little

7. Carya $\times$ ludoviciana $\left(\right.$ C. aquatica $\times$ C. texana) $\left(\right.$ Ashe) $\mathrm{Little}^{y}$

8. Carya $\times$ nussbaumeri $(C$. illinoinensis $\times$ C. laciniosa) Sarg.

9. Carya $\times$ schneckii $\left(C\right.$. illinoinensis $\times$ C. tomentosa) Sarg. ${ }^{y}$

10. C. illinoinensis $\times C$. ovata (see Manning, 1962)

11. C. illinoinensis $\times$ C. myristiciformis (see Grauke and Mendoza-Herrera, 2012).

${ }^{\mathrm{z}}$ Asian species. Section Sinocarya Cheng and R.H. Chang (in Chang and Lu, 1979) has been proposed for all Asian spp. based on naked buds. Those listed in Sinocarya also lack lacunae in nut shells, which Carya poilanei has, as do all members of Apocarya.

${ }^{y}$ Parentage disputed.

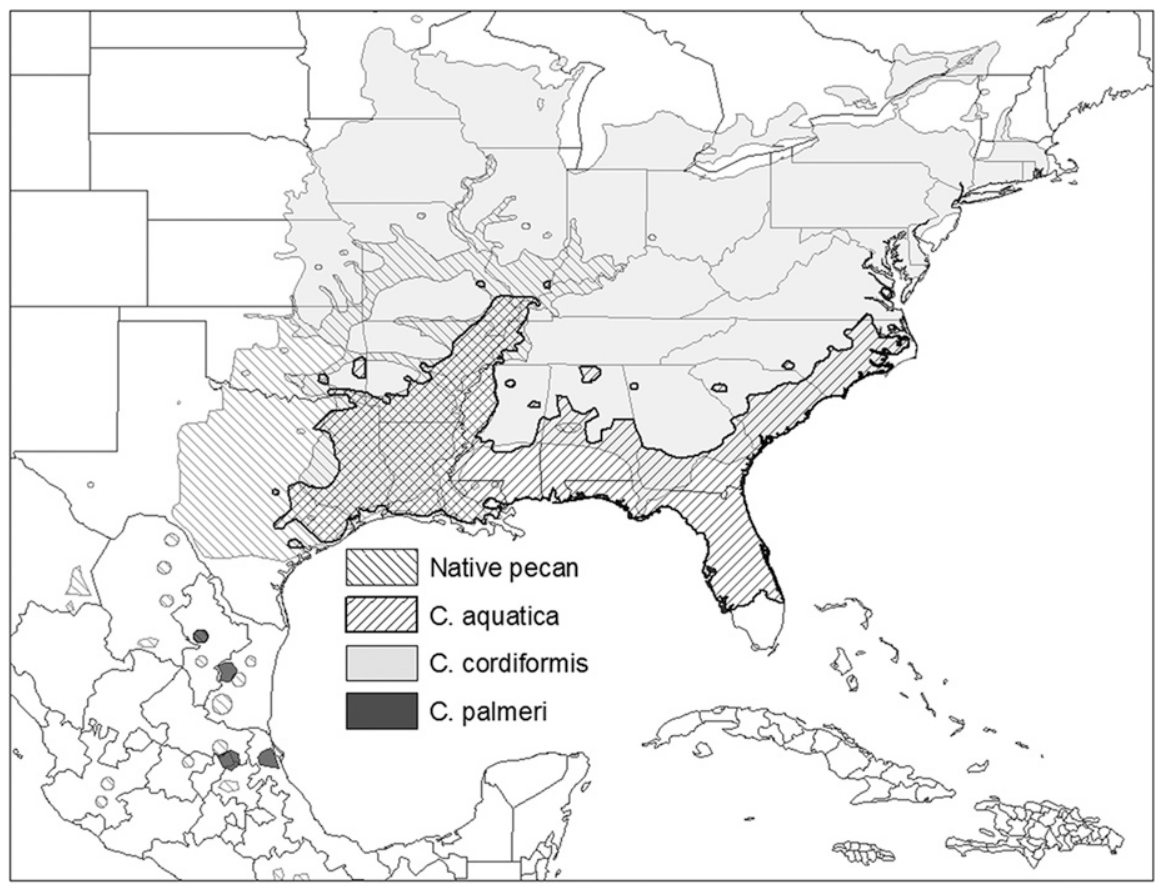

Fig. 5. Distribution of diploid species of section Apocarya.

a consistent downslope in the production trend for natives (Fig. 10). Since native pecans yield less per acre, and nuts are sold at lower prices, there is an increasing incentive to convert native stands to improved orchards.
International. Mexico is second to the United States in the world of pecan production and has recently harvested over $100,000 \mathrm{t}$, accounting for over $40 \%$ of total world production (Table 2) (Branson and
Gibbons, 2011; Nuñez, 2014). Mexican commercial pecan production is largely based on cultivars developed in the United States, primarily 'Western' and 'Wichita', although the recent release of 'Norteña' (Pérez et al., 2015) represents selection from local germplasm which is applauded. Recent crop increases have been due to both increased planting and improved cultural practices, including drip irrigation (Flores and Ford, 2009). Area harvested was estimated at about 70,000 ha in 2014 , with over 82,000 ha planted. Chihuahua is the major pecanproducing state in Mexico, accounting for $50 \%$ to $60 \%$ of national production, followed by Coahuila, Durango, Sonora, and Nuevo Leon (Nuñez, 2014; Puente, 2004). The United States is the main export market for Mexican pecans (Flores and Ford, 2009).

The world's third largest pecan producer is South Africa producing about $2.5 \%$ of the world pecan crop. Pecan production began in the Nelspruit area of Mpumalanga. Current plantings are concentrated to the west, in the Northern Cape Province in the Vaalharts Irrigation district. The climatic conditions of that area are very similar to the U.S. western pecan region. The dry climate is not conducive to the pecan scab disease (Fusicladium effusum Winter) allowing for reduced production costs. Available land, water, and a strong international market for pecans has resulted in accelerated planting of pecans in South Africa, averaging about 4000 ha of new plantations per year. Cultivars being planted there are primarily 'Wichita', 'Choctaw', and 'Navaho', all products of the U.S. Department of Agriculture (USDA) Agricultural Research Service (ARS) Pecan Breeding Program (Grauke and Thompson, 1997). Production in the southern hemisphere has the advantage of being in the off-season of the northern hemisphere, placing their current season crop in competition with the early U.S. pecan harvest for the lucrative Thanksgiving/Christmas holiday gift market. However, about $90 \%$ of the South African crop is sold in-shell to China (Zedan, 2015b).

The pecan industry in Australia was developed largely since the 1960 s, when a portion of the Stahmann family migrated to Australia from the Las Cruces area of New Mexico, where the family pioneered New Mexico pecan production in the 1930s. Most pecans in Australia are produced in New South Wales, with $80 \%$ of production being from the Stahmann Orchards at Moree, New South Wales. Total production area in Australia is currently 1400 ha, with annual production of about $3500 \mathrm{t}$ in-shell or about $1.4 \%$ of the world production. Australian production has the advantage of being in the offseason of the northern hemisphere, placing the current season Australian crop in partial competition with the early pecan harvest in the United States for the lucrative holiday gift market. However, $66 \%$ of Australian production is consumed locally and the remainder is primarily targeted at Asian, rather than U.S. markets. The primary cultivars grown in Australia are standards 


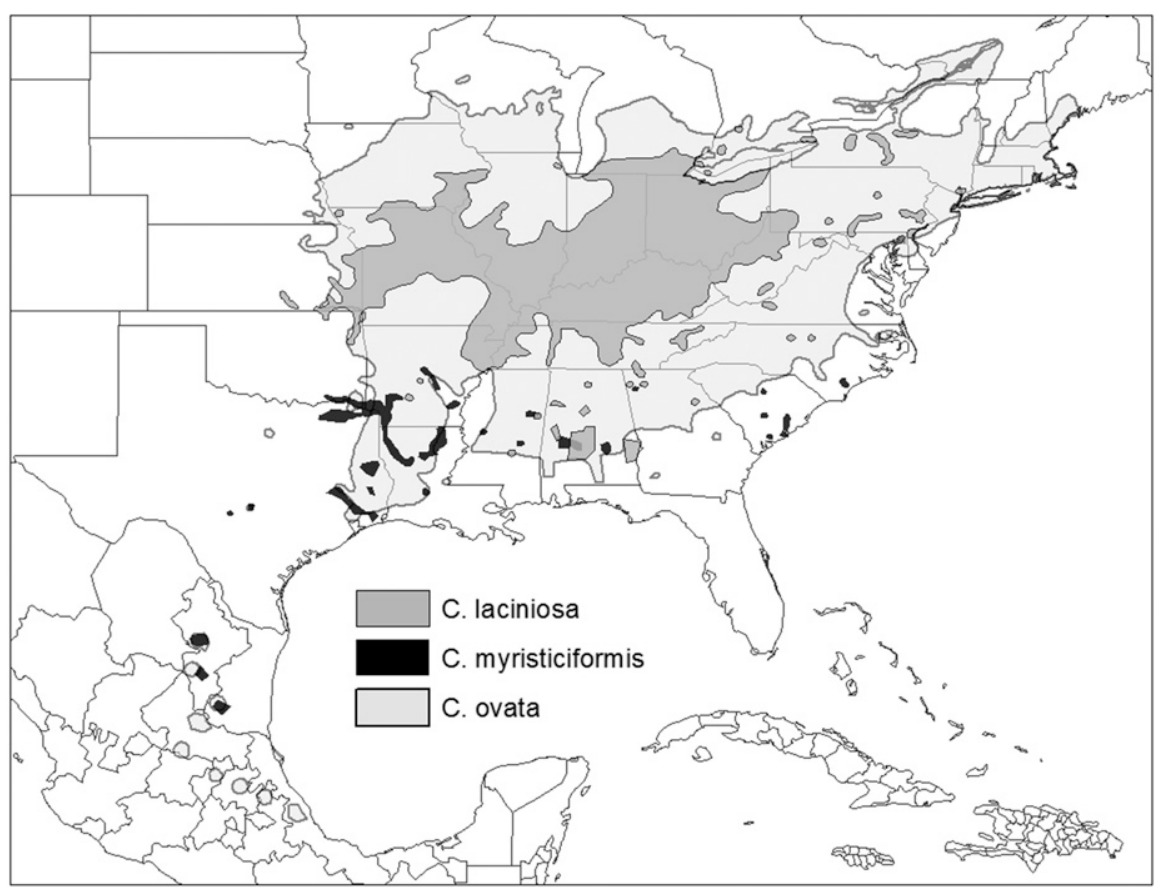

Fig. 6. Distribution of diploid species of section Carya.

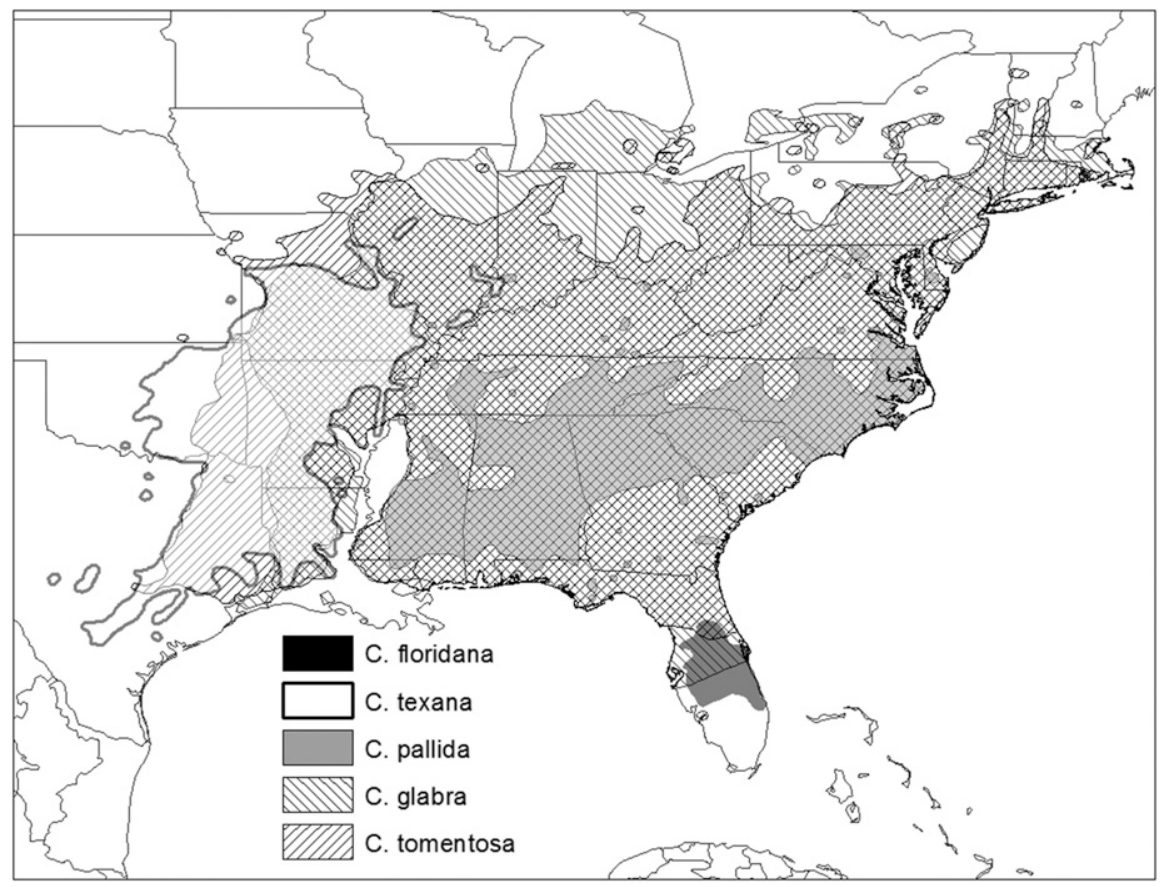

Fig. 7. Distribution of tetraploid species of section Carya.

of the U.S. western pecan industry, such as 'Wichita' and 'Western'.

Pecan nuts are also produced in Argentina, Egypt, Brazil, Uruguay, Chile, Peru, The Peoples Republic of China, India, and Turkey; with small plantings also in the Dominican Republic, Zimbabwe, Israel, Georgia, Italy, Syria, and Iran.

Much of the global attention on pecan is due to increasing consumption in China. China is working to develop its own pecan production industry, building on the historic respect and value given to the perceived health value of nuts in general (Yang and
It was estimated (B. Garris, personal communication) that by 2025 , there would be worldwide production of over $441,000 \mathrm{t}$ $(973,000,000)$ lbs in-shell (an increase of $182 \%$ over current production), with the primary pecan-producing nations being United States $>$ Mexico $>$ South Africa $>$ Australia.

\section{Urgency and Extent of Crop Vulnerabilities and Threats to Food Security}

\section{Genetic uniformity in the "standing crops" and varietal life spans}

Improved pecan culture is a young industry, developed from a diverse native forest of long-lived trees. The "standing crop" includes both indigenous "native" trees and the established orchards of the "improved" pecan industry. The first grafted pecan orchard was propagated by the slave gardener Antoine at Oak Alley Plantation, LA, in 1846 (Taylor, 1905). Individual pecan trees are long lived and commonly survive over 200 years. Given individual tree longevity, unselected native trees still bearing nuts are older than the U.S. commercial pecan industry. The genetic diversity of the native pecan forest has always been assumed to be robust, but systematic methods of characterizing that diversity have not been applied. Increasing evidence indicates that the geographic distribution of genetic diversity reflects long-term adaptation (Bock et al., 2016; Grauke et al., 2011; Sagaram et al., 2011; Sparks, 2005). Characterization of extant diversity in ex situ collections should contribute to breeding and selection.

The historic trend in pecan culture has been managed to increase uniformity. Propagation by grafting or budding allows development of large acreages of a few common genotypes. As a cultivar gains regional acceptance in the market, acreage increases. Four cultivars (Stuart, Western, Desirable, and Wichita) accounted for over $57 \%$ of total improved pecan acreage in 1990 (Thompson, 1990). Once selected and propagated by grafting, a cultivar becomes essentially "immortal", as it is re-propagated. 'Desirable', which originated in about 1933, is still among the most commonly planted cultivars in Georgia (Wells, 2014), despite substantial susceptibility to pecan scab disease that necessitates multiple prophylactic fungicide sprays (Wells, 2014). 'Western', introduced in 1916, is still the most commonly planted cultivar in western orchards. 'Pawnee', introduced in 1984, was the first cultivar released for early season nut maturity (Thompson and Hunter, 1985). That trait has contributed to increased profits in the lucrative U.S. holiday markets surrounding Thanksgiving and Christmas. 'Pawnee' is among the most popular cultivars being propagated in Georgia (Wells, 2014), as well as in the north and west (Thompson and Conner, 2012).

Tree longevity, coupled with the time and expense to establish a new orchard, contributes to the challenge of incorporating new 


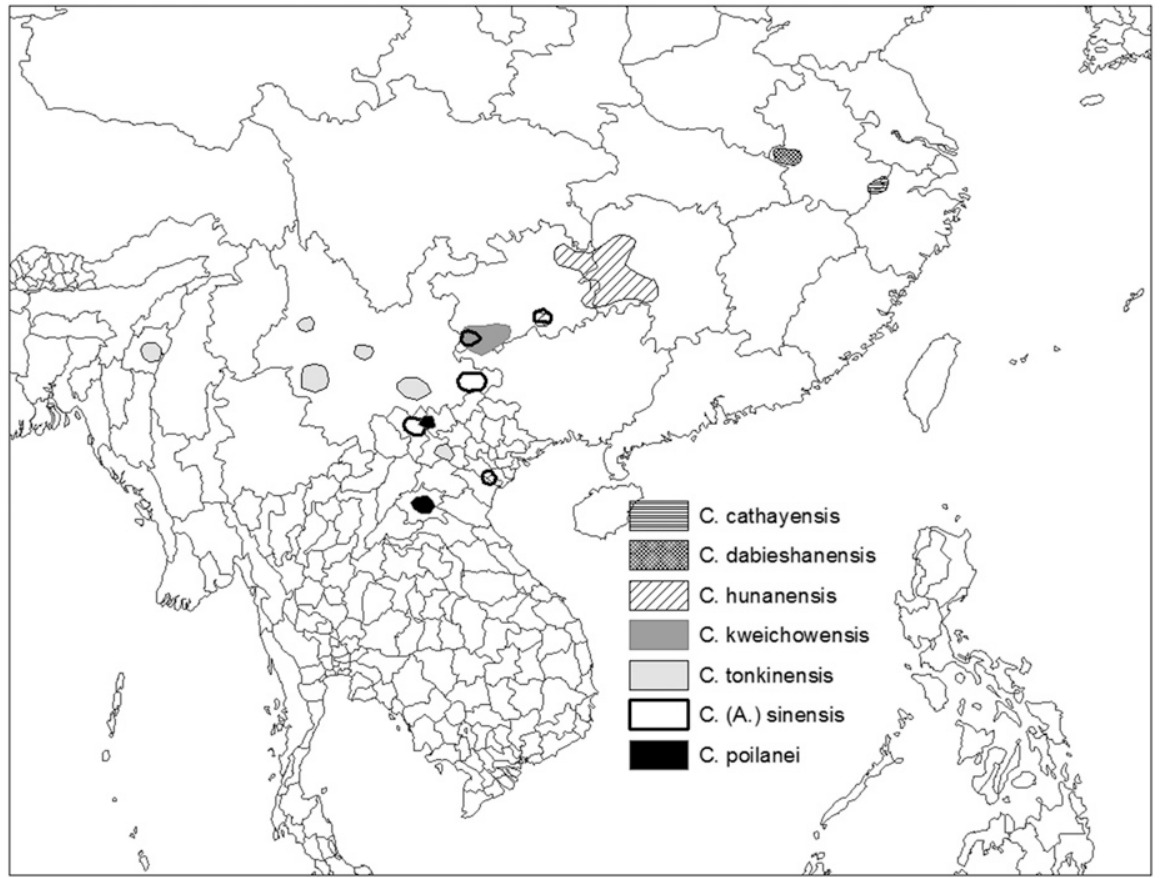

Fig. 8. Distribution of species in section Sinocarya (all diploid).

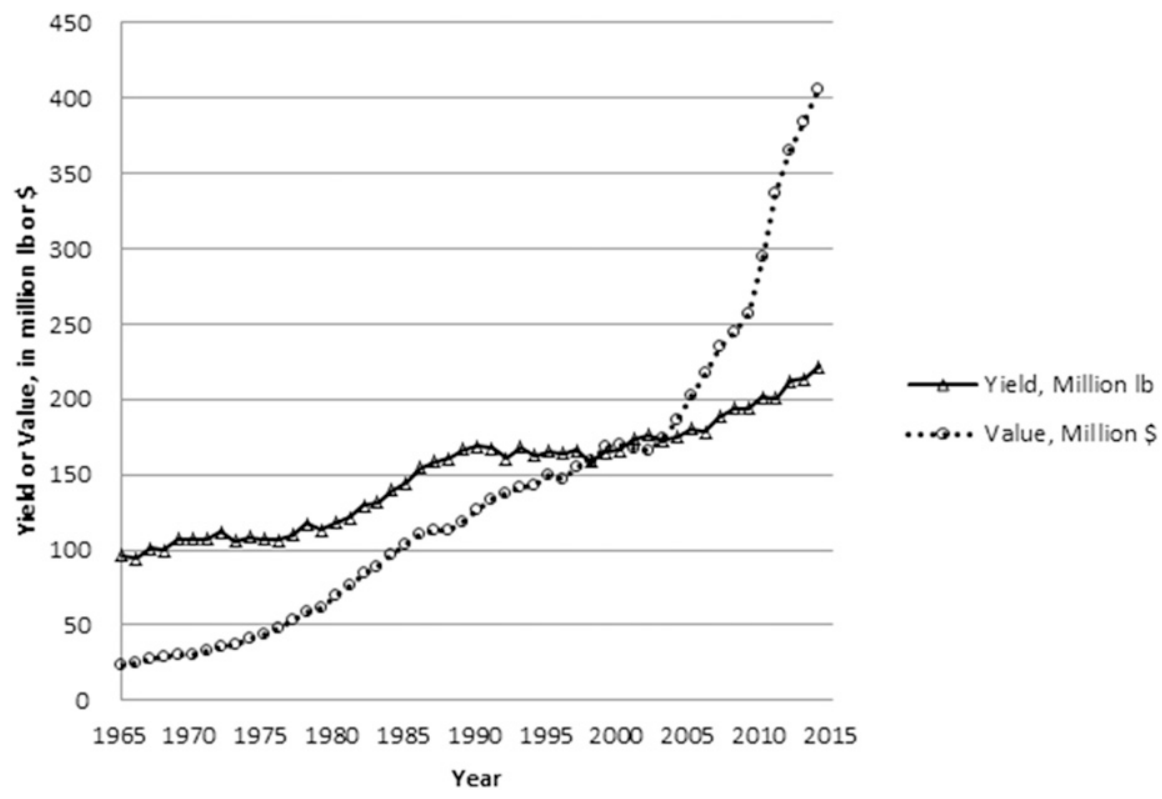

Fig. 9. Fifty years of U.S. 'Improved' pecan yields (million lbs, 10-year running average) in relation to value (million \$, 10-year running average). Data from NASS (2012).

cultivars. Unmanaged orchards that might be considered obsolete can be brought back into production when the incentive of increased price returns, as has been the case since 2003 (Fig. 9). That argues in favor of only offering new cultivars with significantly improved traits of bearing consistency, nut quality, and critical local adaptations for disease and insect resistance.

\section{Threats of genetic erosion in situ}

U.S. Carya species. The genus Carya consists of 17 species worldwide (Table 1). The focus of horticultural attention has historically been on pecan, with the emphasis of stands from wild populations is suspected to have peaked by the middle of the 20th century, with existing native groves consisting of aging trees that are often too large for effective spray management or mechanical harvesting systems. Grazing cattle under trees harvested for nuts raises food regulatory issues that further threaten native culture, increasing the incentive to convert acreage to the less genetically diverse, but more lucrative grafted plantations. Designation of in situ populations that preserve regional genetic diversity while continuing the resilient and historically important cattle/pecan management system may be justified.

Characterization of the geographic distribution of genetic diversity in pecan consistently confirms that the forest holds more diversity than we know how to use (Grauke et al., 2011; Rüter et al., 1999, 2000). Evaluation of diversity in existing ex situ collections of pecan should include more comprehensive screening for resistance to major pests (Harris, 1975). Research on existing collections shows variation in leaf morphology (Grauke et al., 2003; Sagaram et al., 2011) and disease resistance (C. Bock, personal communication) related to geographic origin. Increased resolution with improved genomic tools should aid interpretation of the geographic distribution of genetic diversity. This may motivate return to targeted native areas for further collection. Conservation of in situ populations is invaluable to allow future generations to continue the exploration of this valuable natural resource.

Of the other U.S. Carya species, the most threatened are Carya myristiciformis (Fig. 6) which was described as "nowhere abundant" by Sargent (1918), and is represented by fragmented, disjunct populations that spread from the Atlantic coast to central Mexico, and Carya floridana (Fig. 7) which is endemic to central Florida and has the most restricted distribution of any North American hickory.

Incentive to incorporate valuable traits is necessary to justify the time needed for breeding with hickories. Clinton Graves (Mississippi State University, retired) saw the potential of increased disease resistance with pecan/hickory hybrids (Graves et al., 1982). He made several controlled crosses between pecan and nutmeg hickory that are represented in repository collections, but they offer neither morphological nor molecular evidence of hybridity. Evidence of hybridity with other species in wild populations of nutmeg hickory has been observed following limited examination (Grauke and MendozaHerrera, 2012) and should be systematically evaluated. Carya floridana has the smallest mature tree size among the hickories. Collections from across the species' range were made in 2009 and are well represented in repository collections by self-rooted seedlings. Ploidy is being examined using flow cytometry (Whittemore, Xia, and Grauke, unpublished data) and crosses are being made in the breeding program in an effort to devise strategies to capture the beneficial trait of 


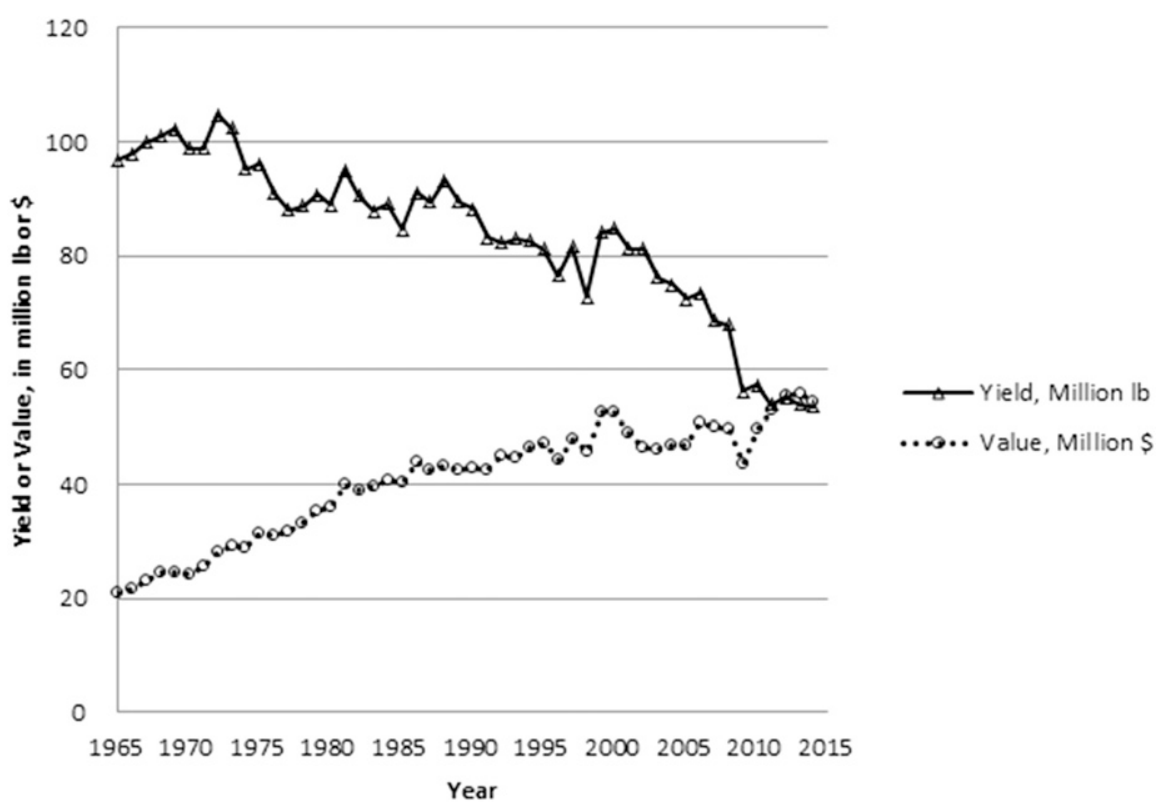

Fig. 10. Fifty years of U.S. 'Native' pecan yields (million lbs, 10-year running average) in relation to value (million \$, 10-year running average). Data from NASS (2012).

Table 2. World pecan production.

\begin{tabular}{lcccc}
\hline Country & Total bearing hectares & Nonbearing hectares & Metric tons & \% of total production \\
\hline United States & 188,622 & 30,607 & 126,174 & 52.0 \\
Mexico & 70,000 & 20,000 & 105,000 & 43.3 \\
South Africa & 6,000 & 21,000 & 6,000 & 2.5 \\
Australia & 1,400 & & 3,274 & 1.4 \\
Others & & & 2,000 & 0.8 \\
Total & & 242,448 & \\
\hline
\end{tabular}

Land area based on information from NASS (2012).

U.S. production $=($ Improved + Native/Seedling $)$ pecans, 2012-14 (NASS, 2012).

reduced tree size, either in rootstocks or scions, both of which will be long-term efforts. Existing in situ populations of $C$. floridana are well conserved by numerous public and private conservation efforts.

Mexican Carya species. Carya in Mexico includes Carya palmeri, C. ovata, and $C$. myristiciformis, in addition to pecan $(C$. illinoinensis). The first three are unrepresented in systematic ex situ collections, but may be represented in some de facto in situ reserves. The three former species are all found in mixed native populations in the mountainous Parque Ecologico Chipinque, south of Monterey, Mexico, where there is evidence of hybrids that include pecan (Grauke and Mendoza-Herrera, 2012). Manning (1962) reported the first interspecific hybrids between pecan and C. ovata from San Luis Potosi, Mexico. Observations in Mexico of early nut maturation in association with low chilling show that pecan accessions from Mexican populations may contribute valuable traits for breeding. Mexican pecan seedlings show outstanding vigor, manifest unusual patterns of plastid diversity, and have patterns of root and leaf morphology likely indicating population level adaptations of value in development of both rootstocks and scions.

Asian Carya species. All Asian hickories occur in fragmented, topographically isolated populations with limited (known) distributions (Fig. 8). It would be valuable to know
(2012) reported patterns in maternally inherited plastid profiles that consistently distinguished specimens of $C$. dabieshanensis from $C$. cathayensis in limited numbers of observations, but such distinctions also separate geographic populations of pecan that are not recognized by even varietal, much less species status (Grauke et al., 2011).

Carya hunanensis, Carya tonkinensis, Carya kweichowensis, and Carya poilanei are not represented in any known systematic ex situ collections. C. hunanensis was tested and found advantageous as a seedling rootstock for C. cathayensis (Huang J.Q. personal communication). C. tonkinensis is occasionally used as a rootstock in Yunnan, but use of the other western Chinese species C. kweichowensis is unknown. Given the rather limited distributions of the Asian Carya species, their characterization and appropriate conservation is encouraged even in the absence of known strategies of utilization.

Debate continues over whether the tree considered by Manning (1963) to be Carya sinensis Dode, is best classified as the monotypic representative of section Rhamphocarya or the monotypic species Annamocarya sinensis (Dode) Leroy (Lu et al., 1999). Regardless of its taxonomic classification, the tree should be incorporated into studies of genetic diversity and its existing populations recognized and preserved by both ex situ and in situ collections. Chinese populations have recently been studied using molecular markers from plastid (matK, rbcL-atpB, rpoC1, rps16, trnH-psbA, and trnL-F) and nuclear genome (ITS and phyA) (Zhang et al., 2013). No ex situ collections of the species have been observed, even at the Nanjing Botanical Gardens. Indigenous stands of the species at Cuc Phuong Forest Reserve in Vietnam were recognized as an important in situ reserve (Grauke et al., 1991) and should be incorporated into systematic characterizations.

Living specimens of $C$. poilanei have not been seen since collections were made from the type tree in Vietnam by Poilane in 1937 (Manning, 1963), although collection efforts have been made in the area where the type was originally found (Grauke et al., 1991; D. Stone, personal communication) as well as in Laos (C. Philaphandeth, personal communication). Because that species had traits that linked Asian species to extinct European species (Mai, 1981), it would be valuable to locate surviving members, if they exist.

Asian species are very poorly represented in U.S. repository collections. We hope to work cooperatively with Asian scientists in developing appropriate molecular methods for characterizing diversity. We encourage establishment of representative Asian ex situ collections where those materials are accessible for study. It is important to establish a baseline profile for each species for phylogeographic interpretations as well as to recognize hybridization that may occur within Asian species when pecan is introduced. 
Current and emerging biotic, abiotic, threats and needs

Biotic (diseases, pests). Xylella fastidiosa is emerging as an important factor in the global stewardship and dissemination of pecan germplasm. The pathogen is a Gramnegative, straight, rod-shaped, aerobic, aflagellate bacterium. It grows optimally from 26 to $28^{\circ} \mathrm{C}$ and is described as "nutritionally fastidious," requiring specialized media for growth in the laboratory. Sanderlin and Heyderich-Alger (2000) reported that $X$. fastidiosa causes leaf scorch in pecan, which has become known as Pecan Bacterial Leaf Scorch (PBLS). A disease screen of commercial cultivars for susceptibility to PBLS (Sanderlin, 2005) reported variable expression of leaf scorch, with all susceptible to infection and symptom development. Graft transmission of the pathogen was demonstrated. Sanderlin and Melanson (2010) demonstrated insect transmission of $X$. fastidiosa by pecan spittlebug, Johnson-grass sharpshooter, and glassy-winged sharpshooter. Melanson et al. (2012) reported that subspecies multiplex infects pecan. Currently, five subspecies of the pathogen are proposed based on molecular sequence similarities: subsp. fastidiosa includes strains that cause disease in alfalfa, almond, grapevine, and maple; subspecies multiplex includes strains causing disease in pecan, almond, elm, peach, pigeon grape, plum, sycamore, and other hardwoods; and subspecies pauca includes strains causing disease in citrus. Subspecies sandyi, was proposed for strains infecting oleander, whereas subspecies tashke was proposed for strains infecting chitalpa in New Mexico (Randall et al., 2009). Once infected with $X$. fastidiosa, the disease is chronic and yields are reduced (Sanderlin and Heyderich-Alger, 2003). Disease transmission via grafting can be reduced by hot water treatment of scions before grafting (Sanderlin and Melanson, 2008). Melanson and Sanderlin (2015) recommended that hot water treatment be adopted as standard phytosanitary treatment in regions that import pecan scion wood. Recent research by Sanderlin (2015) reported that seedlings grown from seven open-pollinated seed stocks differed in susceptibility to infection after mechanical inoculation with $X$. fastidiosa. 'Cape Fear', known to be extremely susceptible as a scion, produced seedling rootstocks that were among the most susceptible, with 'VC1-68' and 'Apache' in the same category. 'Curtis', 'Elliott', and 'Riverside' seedling rootstocks were less susceptible. Seedling rootstocks from 'Moore' and 'Stuart' were intermediate. Since $X$. fastidiosa can be transmitted at high frequency from infected rootstocks to newly grafted trees, selection of resistant rootstocks would be beneficial to pecan nurseries and pecan producers. The foundation clone of the USDA ARS Pecan Breeding Program has been 'Schley' (Grauke et al., 2015). The two most susceptible seed stocks in recent tests (Sanderlin, 2015) are 'Cape Fear' and 'VC1-68', which both have molecular profiles consistent with being direct progeny of 'Schley' (Grauke, unpublished data).

Since a draft of this report was presented and discussed at the Crop Germplasm Committee meeting in Frisco, TX, early July 2015, PBLS was confirmed in Arizona and New Mexico by Drs. Natalie Goldberg and Richard Heerema (Vitanza, 2015). Efforts to characterize the extent of disease distribution and to coordinate protocols for its phenotypic and biochemical identification are underway (J. Randall and K. Ong, personal communication)

International distribution of graftwood has been curtailed by this disease. Phytosanitary inspection protocols call for seasonal inspections, with inventories found to be symptomatic being tested with enzyme-linked immunosorbent assays (ELISAs). The efficacy of ELISA to detect PBLS may depend on refinement of sampling and testing protocols. Steps necessary to protect the domestic pecan industry from distribution of infected wood are being explored.

Regulatory officers dealing with phytosanitary issues require lists of insects and diseases that attack pecan. These lists are in need of update as new pests such as $X$. fastidiosa have been recognized and old pests have been renamed. Updated lists are provided, along with the full Crop Vulnerability Report, at the website of the USDA-ARS Pecan Breeding and Genetics Program (http://cgru.usda.gov/carya). Over time, obsolete names used for a pest may obscure our recognition of an organism. In the list of diseases, synonyms are included to assist those unfamiliar with updated nomenclature. The disease list began with Gottwald et al. (2001), and then relied on the database of Farr and Rossman (2015) for confirmation. References to disease citations are included in the table based on the latter database, with occasional additions. The list of insects that affect pecan began with an unpublished list graciously provided by Bill Ree (TAMU Entomologist). Stan Wellso (USDA ARS Entomologist, retired) added many buprestids known to attack pecan and hickory, and common names have been added when appropriate. That list is also available at the above mentioned website.

International distribution of germplasm requires free exchange of information to help guard against unintentional introduction of pests. A list of insects affecting Carya in China was provided to Marvin Harris by Zhi-hong $\mathrm{Xu}$ (Zhejiang A\&F University, Linan, People's Republic of China) and is being translated and compared with the U.S. list (M. Harris, personal communication). A report of diseases affecting pecan in South Africa (Marais, 2015) includes some not reported in the United States [e.g., Neofusicoccum parvum (Pennycook \& Samuels) Crous, Slippers \& A.J.L. Phillips, Neocosmospora vasinfecta E.F. Sm]. The active involvement of interdisciplinary specialists is necessary to maintain accuracy and currency in these lists.
Abiotic (environmental extremes, climate change). The long-lived nature of pecan orchards and cultivars makes them vulnerable to substantial changes in climate and associated weather events and patterns. Pecan production can be injured by late spring and early autumn freezes, excessive cloud cover, excessive rain during pollination, and drought. Different Carya species are well adapted to different environmental niches, potentially possessing genes that could be introduced into pecan to produce cultivars adapted to new abiotic environments. There is a need to develop pecan rootstocks adapted to specific soil environments, such as extremes in $\mathrm{pH}$, salts, and essential nutrient elements.

\section{Status of Plant Genetic Resources in the NPGS Available for Reducing Genetic Vulnerabilities}

\section{Germplasm collections and in situ reserves}

Holdings. The USDA ARS Pecan Breeding and Genetics Program maintains two worksites where ex situ collections of the NCGR-Carya are held. Both are in Texas: the Brownwood worksite in Brown County, and the College Station worksite in Burleson County. At each location, there are three general categories of holdings: pecan cultivar collections (accessions grafted onto pecan seedling rootstocks), pecan provenance collections (primarily seedlings growing on their own roots, grown from seed collected from geographic populations), and species collections (collected directly from wild trees and held as seedlings on their own roots, grafted to pecan rootstocks, or in some cases received as named cultivars from various sources and grafted to pecan seedling rootstocks).

Brownwood: The Brownwood worksite is the original home of the USDA ARS Pecan Breeding and Genetics Program, with a history tracing back to 1930 . The worksite includes a total of 96.7 ha, of which 62.7 ha are owned by the City of Brownwood and made available to USDA ARS under a memorandum of understanding. Almost 2 ha and all headquarters buildings located at 701 Woodson Road were donated by the city to ARS in 1973 (and accepted by USDA in 1976). An additional 32 ha of land adjacent to the station was purchased by ARS in 1978 as a permanent site for the National Clonal Germplasm Repository which was officially designated in 1984. Louis Romberg, the first ARS breeder, began grafting selected cultivars at Brownwood in the early 1930s for use as parents in breeding. Those collections were the reason the site was designated in 1984 as the NCGR-Carya (Postman et al., 2006). The National Plant Germplasm System mandated that plants within the system be "backed up" by additional inventories to avoid catastrophic loss of accessions. Collections have been transferred from land owned by the City of Brownwood onto ARS owned land, and materials transferred from each 
worksite to the other. Grafted accessions of the NCGR-Carya at Brownwood are found as isolated, old trees all across the Old Main Orchard, but are concentrated in the Romberg Block and C-Pans of the City Orchards. Since 1991, grafted accessions have been added to the NCGR BWV orchard, now occupying 5.7 of 22 ha available on ARS land contiguous to the original orchards. The oldest inventories of grafted accessions at the Brownwood orchard were used to develop molecular methods for cultivar identity (Marquard et al., 1995) as well as for subsequent microsatellite profiles, and are invaluable for the integrity of cultivar verification.

There are 354 grafted accessions in the Brownwood orchards, including 96 that are not present in College Station. Ninety-five percent of the grafted accessions at Brownwood are pecan, with $5 \%$ being other species of Carya. A small provenance collection is maintained at Brownwood, comprised of only 120 pecan seedlings growing on their own roots, representing 63 mother trees from 49 populations. The planting consists of selfrooted seedling trees in a low-maintenance planting of 2.9 ha (of 9.75 ha available).

College Station: The College Station worksite was obtained by leasing 145.7 ha of land from Texas A\&M University. The 99-year lease was initiated in 1987 and will expire in 2086. Initially, primary use of the site was as nurseries for the Pecan Breeding Program and as test orchards in the National Pecan Advanced Clone Testing System. College Station collections include 349 grafted accessions, 91 of which are not present in Brownwood. The majority of Carya species collections are maintained at the College Station worksite. The majority of provenance orchards are maintained at the College Station worksite (over 2000 self-rooted trees growing on about 12 ha, representing native pecan populations from Mexico to Missouri, with detailed collections from Arkansas and coastal Louisiana). A small seedling population from a noteworthy putatively native stand in Alabama is also maintained.

Associated collections: The Southeastern Fruit and Tree Nut Laboratory in Byron, GA, maintains significant collections of pecan cultivars, self-rooted hickory seedlings (Wood and Grauke, 2011), and an excellent pecan provenance collection (Bock et al., 2016; Grauke et al., 1989; Rüter et al., 1999, 2000; Wood et al., 1998). The pecan provenance orchard at Byron, GA, was established before the establishment of provenance orchards at the College Station worksite, from the same seed sources, and constitutes an exceptionally valuable resource for the pecan industry. Phenotypic evaluations of leaf area and nutrient content have been cooperatively reported (Grauke et al., 2003). Selected accessions were evaluated for nut quality and genotyped using microsatellites (Grauke et al., 2011).

\section{Associated information}

Genebank and/or crop-specific web site(s). Accessions are listed on the Germplasm Resources Information Network and the program website at www.CGRU.usda.gov/ Carya. Both are continuously updated.

Passport information. Summaries of pecan cultivar origination records published by Thompson and Young (1985) form the foundation of cultivar passport information and are available for most commercial cultivars on the program website (http://cgru.usda. gov/Carya/pecans/cvintro.htm). Accessions have been georeferenced to provide estimates of latitude and longitude based on details available in acquisition information. Molecular profiling offers confirmation or correction at all nomenclatural levels and is ongoing.

Genotypic characterization data. About 170 pecan cultivars were profiled for malate dehydrogenase, phosphoglucose isomerase, phosphoglucomutase, leucine aminopeptidase, and diaphorase (Marquard et al., 1995). About 800 pecan seedlings from provenance collections at College Station were evaluated for the same isozymes (Grauke et al., 1995), and over 200 of those inventories still exist in provenance plantations in College Station and Brownwood.

Microsatellite profiles at 14 nuclear loci and 3 plastid loci have been developed for about 180 inventory specific pecan cultivars, $\approx 260$ pecan seedlings in provenance collections at College Station, TX, and Byron, GA, and $\approx 180$ hickory samples from repository collections (not all maintained as living accessions).

Several cases of "identity confusion" have been resolved using microsatellite markers (Grauke et al., 2015). Profiles of most commercially important U.S. pecan cultivars have been developed using microsatellite markers. Existing SSR profiles provide molecular verification of identity within our collections. Those profiles have proven useful in identifying unknown accessions sent for determination, since parentage can often be inferred. Currently, no commercial laboratories are using the pecan microsatellites, possibly because of the challenges of consistently scoring fragment-based markers. Standard methods are needed to allow comparison of results obtained from different analysis platforms.

Using inventories of accessions maintained at the Southeastern USDA-ARS Fruit and Tree Nut Laboratory in Byron, GA, patterns of genetic diversity have been shown to vary with geographic distribution over the range of pecan, with markers on maternally inherited plastids being more closely related to geographic distribution than nuclear markers (Grauke et al., 2011).

A Carya diversity panel with 50 entries was analyzed for single nucleotide polymorphism (SNPs) on the Juglans SNP chip (You et al., 2012) by colleagues working with walnut at the NCGR-Davis and University of California, Davis. With the help of Dr. David Kuhn (USDA-ARS Miami), the results of the Carya panel have been interpreted and used to generate an informative phylogenetic tree. The most informative SNPs were identified and primers developed for
222 SNP loci. Those are being evaluated for polymorphism using an eight-member diversity panel using Kompetitive Allele Specific PCR.

Two accessions of pecan ('Pawnee' and 87MX3-2.11) were selected to investigate the feasibility of generating a pecan reference sequence. They were selected due to the extensive use of 'Pawnee' in current breeding progenies, and the low level of polymorphism observed in the $87 \mathrm{MX} 3-2.11$ accession, based on microsatellite analysis. Isolated DNA was used by HudsonAlpha Genome Sequencing Center to produce a draft survey sequence for pecan (Jenkins et al., 2015). The draft assembly allows SNP discovery, provides a scaffold to which other Carya genomic sequence may be aligned and has formed the foundation for the development of a community strategy for further development of genomic tools for pecan. A PowerStation Gx2 Starter computing platform (PSSC Labs, Lake Forest, CA) running a Linux (Red Hat Enterprise, Raleigh, NC) operating system and CLC Genomics Workstation software (CLC Bio, Waltham, MA) was obtained to house and work with that data in 2013. Preliminary efforts at RAD-Seq by USDA ARS in conjunction with Dr. P. Klein (Texas A\&M University) have yielded sequence information that has been aligned to the survey scaffolds, and provided a large numbers of SNPs and microsatellite loci for development, given sufficient resources. Mattison et al. (2013) measured transcript levels of three nut allergens from 'Desirable' and 'Sumner' over the course of nut development using reverse transcription quantitative polymerase chain reaction. Those transcripts have been shared with Dr. Jennifer Randall at New Mexico State University, who is using the sequence information to annotate the draft survey sequence (Barnes et al., 2016).

Phenotypic evaluation data. Extensive nut quality information (nut length, width, height, weight, volume, and percent kernel), typically from several seasons, is collected for fruiting accessions of NCGR-Carya collections. Those collections are represented by standardized digital photographs of nuts and kernels. A small number of those images are available on the unit website. Extent of dichogamy is known for most named pecan cultivars and photographs of catkin and pistillate flowers are available for many of the College Station accessions. Leaf and nut scab ratings based on the Hunter-Roberts scale of worst expression have been accumulated over multiple seasons, but disease is often not expressed under Texas' climate conditions.

Analysis of broad pecan provenance collections has shown that leaf morphology varies in geographic patterns that might have adaptive significance (Grauke et al., 2003; Sagaram et al., 2007, 2011). Current research in provenance orchards (J. Bernal, unpublished data) confirms that leaf morphology, including leaf pubescence, varies between provenances and may impact insect populations on trees grown in a common garden. 
Open-pollinated seed stocks from repository collections were used in screening efforts to find resistance to nematodes. Sources of nematode resistance were not found. Seedlings showed patterns of growth phenology and vigor that varied between provenances of origin. Seedlings from southern sources began growth first, continued growth longest, and achieved greatest diameters and heights (Grauke and Starr, 2014).

\section{Prospects and Future Developments}

The U.S. pecan industry is regionally fragmented, with management and production constraints based on climatic and edaphic variation across diverse growing regions, coupled with regional competition for limited markets. It is also characterized by division between pecan producers and the nut shelling industry that has traditionally controlled marketing and is increasingly important in the protection of food safety. International interest in the crop is increasing, as evidenced both by increased exports of the U.S. crop and increased pecan production in other countries. In both the United States and other countries, commercial production relies on a small subset of selected genotypes. The USDA ARS Pecan Breeding and Genetics Program is responsible for breeding and development of the pecan, as well as for the collection, characterization, evaluation, maintenance, and international distribution of Carya germplasm. The U.S. pecan producing industry is uniting toward the goal of improving domestic and international marketing, but is apprehensive about the distribution of improved pecan cultivars to competitor nations. The U.S. pecan research community has been focused on local crop production issues, and grant application attempts seeking broad cooperation on longterm strategic research have been unsuccessful (Stevenson, 2012).

The driving force for increasing knowledge about the genus Carya has been the economic value of the pecan nut production industry, which motivated the development of the USDA ARS Pecan Breeding Program in the early 1930s. Pecan cultivars collected for use in breeding became the foundation of the National Clonal Germplasm Repository, which was designated in the early 1980 s (Postman et al., 2006). That collection has expanded to the current NCGR-Carya. The program has experienced reductions in personnel and budget, while the mandate to collect from "worldwide sources of wild species and domestic cultivars to provide for maximum genetic diversity in each genus" (Westwood, 1986) has not changed. The Carya Crop Germplasm Committee Report of 1997 (http://cgru.usda.gov/carya/cgc/ cgc97.htm) noted admonitions from leading botanists to describe, inventory and map biotic diversity (Raven et al., 1992; Soule 1990). That process is ongoing and is incentivized by the recognition of the contributions of crop wild relatives to recently released U.S. pecan cultivars (Grauke et al.,
2015). Areas needing future attention include isolated, relatively uncharacterized populations of indigenous Carya species in Mexico and Asia. The motivation to accomplish those inventories is increased by the distribution of exotic germplasm into those areas, and the increased recognition of the frequency of interspecific hybridizations that can impact indigenous populations. The rapid destruction of local native pecan populations argues in favor of continuing broad characterizations of the distribution of genetic and geographic diversity to better understand adaptation and facilitate development of regional cultivars and rootstocks.

National Plant Germplasm System collections are mandated to distribute germplasm to both domestic and international cooperators. The recognition of a pathogen such as $X$. fastidiosa, which could be distributed inadvertently along with germplasm, requires the development and refinement of phytosanitary certification procedures relevant to both domestic and international cooperators.

Cooperative germplasm evaluation and exchange will benefit by the rapid development of improved analytical methods and phytosanitary protection. Increasing access to the broad diversity of the genus should open new opportunities for crop improvement through the application of genomic methods applied to appropriate populations that have been well characterized phenotypically (Ouborg et al., 2010). The motivation for maintaining diversity within the NPGS has always been clear: human need (utility) is the primary criterion for genetic conservation. However, since the primary users of genetic collections are crop breeders (Namkoong, 1991; Palmer, 1989), it is necessary to establish effective cooperation across regional breeding programs. The 29 pecan cultivars that have been released over the 85-year history of the USDA ARS Pecan Breeding Program have all been distributed without charge to the U.S. pecan nursery industry for propagation. They represent diverse parentage that inadvertently incorporated genes from crop wild relatives. Most were released after cooperative testing across regions. The 14 cultivars released since 1984 required an average of 35 years from the original cross until release. Purposefully incorporating crop wild relatives in breeding populations targeting advantageous traits such as reduced tree size, while avoiding deleterious traits such as reduced production and nut quality, will either greatly extend the time required for cultivar development or will require improved methods of genomic selection.

Conner (2015) noted several problems facing the pecan research community in the development of practical genomic tools for use in breeding, with the first being the small number of scientists involved in the effort. He outlined a strategy necessary for success that called for development of a reference genome sequence, development of better phenotyping methods, and development of a standardized segregating population replicated across regions. The standardized segregating population would require regional and multi-institutional cooperation, would provide means to analyze environmental effects on genetic expression, and would provide a platform for development of improved phenotyping methods.

Existing ex situ collections of the NCGRCarya should be cooperatively evaluated using available genomic methods. Cooperative strategic planning of appropriate controlled crosses for use as shared mapping populations, followed by aggressive phenotypic screening and genomic evaluation, should produce demonstrably refined methods of progeny selection while further developing the "road map" of progressively improving genomic information. The fruit of those efforts will be accessible to future students of the genus only if the information linking verified living inventories of accessions, the passport information describing their origination, and phenotypic characterizations already accumulated can be associated with genomic characterizations. Pecan cultivar development is necessarily multidisciplinary, increasingly international in scope, and will be facilitated by a central database serving the accumulated information. Although much of that information can be appropriately maintained within the GRINGlobal database, genomic and bioinformatic utilities will necessitate cooperative development with other scientists and industry users that is beyond the scope of existing program budgets. We have access to a collection that represents a global forest. As stewards of that resource, we must now use it.

\section{Literature Cited}

Ares, A., W. Reid, and D. Brauer. 2006. Production and economics of native pecan silvopastures in central United States. Agrofor. Syst. 66:205-215.

Barnes, S.D., H. Zhong, L.J. Grauke, C.P. Mattison, R.A. Stamler, J. Schmutz, J. Jenkins, R. Heerma, M.Z. Song, and J.A. Randall. 2016. Computational annotation of the pecan genome. Plant and Animal Genome Conference XXIV. Poster 1135. <https://pag.confex.com/ pag/xxiv/webprogram/Paper21241.html>.

Bock, C.H., L.J. Grauke, P.J. Conner, S.L. Burrell, M.W. Hotchkiss, D.L. Boykin, and B.W. Wood. 2016. Scab susceptibility of a provenance collection of pecan in three different seasons in the Southeastern USA. Plant Dis. (In press).

Branson, A. and A. Gibbons. 2011. Mexico. Tree nuts annual: Pecan, macadamia, pistachio, walnut and almond situation. Global Agricultural Information Network (GAIN) Report Number MX1069.

Chang, J.H. and A.M. Lu. 1979. A study of the genus Carya Nutt. in China. Acta phytotaxonomica Sinica 17(2):40-44.

Chung, S.C., M.K. Harris, and J.B. Storey. 1995. Masting in pecan. J. Amer. Soc. Hort. Sci. 120:386-393.

Conner, P.J. 2015. Roadblocks and hindrances to the development of molecular tools in pecan (Carya illinoinensis): a breeder's perspective. Acta Hort. 1070:83-87.

Farr, D.F. and A.Y. Rossman. 2015. Fungal databases, systematic mycology and microbiology 
laboratory. USDA-ARS. 23 June 2015. <http:// nt.ars-grin.gov/fungaldatabases/>.

Flores, D. and M. Ford. 2009. Mexico. Tree nuts annual 2009. Global Agricultural Information Network (GAIN) Report Number MX9061.

Gottwald, T.R., P.F. Bertrand, T.J. Michailides, and B.L. Teviotdale. 2001. Diseases of pecan (Carya illinoinensis (Wang.) Koch.). <http:// www.apsnet.org/publications/commonnames/ Pages/Pecan.aspx $>$.

Grauke, L.J., R.R. Klein, M.A. Grusak, and P.E. Klein. 2015. The forest and the trees: Applications for molecular markers in the Pecan Breeding Programs. Acta Hort. 1070:109-126.

Grauke, L.J. and M.A. Mendoza-Herrera. 2012. Population structure in the genus Carya. Acta Hort. 948:143-158.

Grauke, L.J., M. Mendoza-Herrera, A. Miller, and B.W. Wood. 2011. Geographic patterns of genetic variation in native pecans. Tree Genet. Genomes 7(5):917-932.

Grauke, L.J., J.A. Payne, and B.W. Wood. 1989. North American pecans: A provenance study. Annu. Rpt. North. Nut Growers Assn. 80:124-131.

Grauke, L.J. and J.L. Starr. 2014. Phenotypic screening of pecan seedling rootstocks in search of nematode resistance. Trees 28:1333-1341.

Grauke, L.J., J.B. Storey, T.E. Thompson, and B.W. Wood. 2003. Leaf structure and nutrient content vary in native pecan populations. Proc. Tex. Pecan Growers Assn. 70:59-60.

Grauke, L.J. and T.E. Thompson. 1997. Pecan, p. 544-562. In: The Brooks and Olmo register of fruit \& nut varieties. 3rd ed. ASHS Press, Alexandria, VA.

Grauke, L.J., T.E. Thompson, and R.D. Marquard. 1995. Evaluation of pecan germplasm collections and designation of a preliminary core subset. HortScience 30:950-954.

Grauke, L.J., B.W. Wood, and J.A. Payne. 1991. Genetic resources of Carya in Vietnam and China. Annu. Rpt. North. Nut Growers Assn. 82:80-87.

Graves, C.H., Jr., G. Windham, P.A. Hedin, and W.W. Neel. 1982. The potential of interspecific crosses in developing disease and insect resistant cultivars. Southeastern Pecan Growers Assn. 75:99-104.

Guo, C.Y., B.B. Wang, Y.Z. Lü, and X.W. Zhang. 2015. RAPD analysis on genetic diversity of wild populations of Carya cathayensis in southern mountainous area of Anhui Province. Chinese J. Ecol. 34(5):1301-1306.

Harris, M.K. 1975. Allopatric resistance: Searching for sources of insect resistance for use in agriculture. Environ. Entomol. 4:661-669.

Harris, M.K. 1980. Arthropod-plant interactions related to agriculture, emphasizing host plant resistance, p. 23-51. In: M.K. Harris (ed.). Biology and breeding for resistance to arthropods and pathogens in agricultural plants. Texas A\&M University, College Station, TX. MP-1451.

Huang, Y.J., L.L. Liu, J.Q. Huang, Z.J. Wang, F.F. Chen, Q.X. Zhang, B.S. Zheng, and M. Chen. 2013. Use of transcriptome sequencing to understand the pistillate flowering in hickory (Carya cathayensis Sarg.). BMC Genomics 14:691.

Jenkins, J., B. Wilson, J. Grimwood, J. Schmutz, and L.J. Grauke. 2015. Towards a reference pecan genome sequence. Acta Hort. 1070:101-108.

Li, J., Y. Zeng, D. Shen, G. Xia, Y.Z. Huang, Y.J. Huang, J. Chang, J.Q. Huang, and Z. Wang. 2014. Development of SSR markers in hickory (Carya cathayensis Sarg.) and their transferability to other species of Carya. Curr. Genomics 15(5):1-23.
Liu, M.C. and Z.J. Li. 1984. A new species of Carya from China (in Chinese). J. Zhejiang For. College 1(1):41-43.

Lu, A.M., D.E. Stone, and L.J. Grauke. 1999. Juglandaceae, p. 277-285. In: Z.Y. Wu and P.H. Raven (eds.). Flora of China. Vol. 4. Cycadaceae through Fagaceae. Science Press, Beijing, China/Missouri Botanical Garden Press, St. Louis, MO.

Mai, D.H. 1981. Der Formenkreis der Vietnam$\mathrm{Nu}$ (Carya poilanei (Chev.) Leroy) in Europa. Feddes Repert. 92:5-6.

Manning, W.E. 1962. Additional notes on Juglans and Carya in Mexico and Central America. Bull. Torrey Bot. Club 89(2):110-113.

Manning, W.E. 1963. Hickories reported in India and Laos with other notes on Carya in Asia. Brittonia 15(2):123-125.

Marais, G.J. 2015. Pecan diseases in South Africa. Report to South Africa Pecan Producers Association. 1 Jan. 2016. <http://www.pecan-nut. co.za/wp-content/uploads/2015/12/Report-2Article-Diseases-of-pecans-in_-South-AfricaSAPPA.pdf>.

Marquard, R.D., L.J. Grauke, T.E. Thompson, and R.S. Janos. 1995. Identifying pecan cultivars by isozymes and inheritance of leucine aminopeptidase. J. Amer. Soc. Hort. Sci. 120:661-666.

Mattison, C.P., M.R. Tarver, C. Florane, and C.J Graham. 2013. Temporal expression of pecan allergens during nut development. J. Hort. Sci. Biotechnol. 88(2):173-178.

Melanson, R.A. and R.S. Sanderlin. 2015. Hotwater treatment of pecan scions as a means of phytosanitation to reduce the potential introduction of Xylella fastidiosa, the causal agent of Pecan Bacterial Leaf Scorch, into orchards and new geographic regions. Acta Hort. 1070:201-209.

Melanson, R.A., R.S. Sanderlin, A.R. McTaggart, and J.H. Ham. 2012. A systematic study reveals that Xylella fastidiosa strains from pecan are part of $X$. fastidiosa subsp. Multiplex. Plant Dis. 96:1123-1134.

Namkoong, G. 1991. Maintaining genetic diversity in breeding for resistance in forest trees. Annu. Rev. Phytopathol. 29:325-342.

NASS. 2012. Census of agriculture. USDA National Agricultural Statistics Service (NASS).

Nuñez, H. 2014. Situación del cultivo del nogal en superficie plantada y cosechada, volumen de producción, rendimiento unitario, precio por tonelada y valor de la producción en 2013 en México (Servicio de Información Agroalimentaria y Pesquera). La Mesa Redonda Maqueada de Nogal. Numero 373:1. 25 July.

Ouborg, N.J., C. Pertoldi, V. Loeschcke, R. Bijlsma, and P.W. Hedrick. 2010. Conservation genetics in transition to conservation genomics. Trends Genet. 26(4):177-187.

Palmer, R.G. 1989. Germplasm collections and the experimental biologist, p. 32-45. In: A.H.D. Brown, O.H. Frankel, D.R. Marshall, and J.T. Williams (eds.). The use of plant genetic resources. Cambridge University Press, Cambridge.

Pérez, H.A., J.A. Ávila, E.M. Olais, E.C. Villarreal, A.L. Murrieta, H.T. Rivero, J.H. Núñez-Moreno, and L. Lombardini. 2015. 'Norteña' pecan. HortScience 50:1399-1400.

Postman, J., K. Hummer, E. Stover, P. Forsline, L.J. Grauke, F. Zee, T. Ayala-Silva, R. Krueger, B. Irish, and P. Bretting. 2006. Fruit and nut genebanks in the US National Plant Germplasm System. HortScience 41:1188-1194.

Puente, A. 2004. Projected pecan production trends in Mexico. Agricultural production trends and the future of the trans-boundary Rio Grande/
Rio Bravo Basin. Conference Proceedings. p. 6-10.

Randall, J.J., N.P. Goldberg, J.D. Kemp, M. Radionenko, J.M. French, M.W. Olsen, and S.F. Hanson. 2009. Genetic analysis of a novel Xylella fastidiosa subspecies found in the southwestern United States. Appl. Environ. Microbiol. 75:5631-5638.

Raven, P., R. Norgaard, C. Padoch, T. Panayotou, A. Randall, M. Robinson, and J. Rodman. 1992. Conserving biodiversity: A research agenda for development agencies. National Academy Press, Washington, DC.

Rüter, B., J.L. Hamrick, and B.W. Wood. 1999. Genetic diversity within provenance and cultivar germplasm collections versus natural populations of pecan (Carya illinoinensis). J. Hered. 90:521-528.

Rüter, B., J.L. Hamrick, and B.W. Wood. 2000. Outcrossing rates and relatedness estimates in Pecan (Carya illinoinensis). Populations. J. Heredity 91:72-85.

Sagaram, M., L. Lombardini, and L.J. Grauke. 2007. Variation in leaf anatomy of pecan cultivars from three ecogeographic locations. J. Amer. Soc. Hort. Sci. 132:1-5.

Sagaram, M., L. Lombardini, and L.J. Grauke. 2011. Variation in anatomical characteristics in leaves of pecan seedstocks from Mexico and the United States. J. Amer. Soc. Hort. Sci. 136:103-108

Sanderlin, R.S. 2005. Cultivar and seedling susceptibility to pecan bacterial leaf scorch caused by Xylella fastidiosa and graft transmission of the pathogen. Plant Dis. 89:446-449.

Sanderlin, R.S. 2015. Susceptibility of some common pecan rootstocks to infection by Xylella fastidiosa. HortScience 50:1183-1186.

Sanderlin, R.S. and K.I. Heyderich-Alger. 2000. Evidence that Xylella fastidiosa can cause leaf scorch disease of pecan. Plant Dis. 84:1282-1286.

Sanderlin, R.S. and K.I. Heyderich-Alger. 2003. Effects of pecan bacterial leaf scorch on growth and yield components of cv. Cape Fear. Plant Dis. 87:259-262.

Sanderlin, R.S. and R.A. Melanson. 2008. Reduction of Xylella fastidiosa transmission through pecan scion wood by hot-water treatment. Plant Dis. 92:1124-1126.

Sanderlin, R.S. and R.A. Melanson. 2010. Insect transmission of Xylella fastidiosa to pecan. Plant Dis. 94:465-470.

Sargent, C.S. 1918. Notes on North American trees. II. Carya. Bot. Gaz. 66:229-258.

Soule, M.E. 1990. The real work of systematics. Ann. Mo. Bot. Gard. 77:4-12.

Sparks, D. 2005. Adaptability of pecan as a species. HortScience 40:1175-1189.

Stevenson, T. 2012. From the farm: 'Enough is enough! Pecan South 45(5):12-14.

Taylor, W.A. 1905. Promising new fruits, p. 399 416. In: G.M. Hill (ed.). Yearbook of the Department of Agriculture 1904. Government Printing Office, Washington DC

Thompson, T.E. 1990. Update pecan cultivars: Current use and recommendations. Pecan S. 24(1):1220.

Thompson, T.E. and P.J. Conner. 2012. Pecan, p. 771-800. In: M.L. Badenes and D.H. Byrne (eds.). Fruit breeding, handbook of plant breeding. Vol. 8. Springer-Verlag, New York, NY.

Thompson, T.E. and R.E. Hunter. 1985. 'Pawnee' pecan. HortScience 20:776.

Thompson, T.E. and L.D. Romberg. 1985. Inheritance of heterodichogamy in pecan. J. Hered. 76:456-458.

Thompson, T.E. and F. Young, Jr. 1985. Pecan cultivars-past and present. Texas Pecan Growers Association Inc., College Station, TX. 
Vitanza, S. 2015. Issues in agriculture. Newsletter about integrated pest management for the El Paso Valley. Vol. 40, Issue 9. Texas A\&M AgriLife Extension. Sept. 22.

Wang, Z.J., J.Q. Huang, Y.J. Huang, F.F. Chen, and B.S. Zheng. 2012. Cloning and characterization of a homologue of the FLORICAULA/ LEAFY gene in hickory (Carya cathayensis Sarg). Plant Mol. Biol. Rpt. 30:794-805.

Wells, L. 2014. Pecan planting trends in Georgia. HortTechnology 24:475-479.

Westwood, M.N. 1986. Operations manual for the National Clonal Repositories. Processed report. USDA-ARS and Oregon State Univ., Corvallis, OR.

Wise, C.L. 2010. Georgia industry energized, planting and renovating. Pecan South 43(4): $17-27$.
Wood, B.W. and L.J. Grauke. 2011. The rare-earth metallome of pecan and other Carya. J. Amer. Soc. Hort. Sci. 136:389-398.

Wood, B.W., L.J. Grauke, and J.A. Payne. 1998. Provenance variation in pecan. J. Amer. Soc. Hort. Sci. 123:1023-1028.

Yang, Z.Z. and F. Gale. 2015. Fruit and tree nuts outlook: Economic insight. China's potential as an export market for tree nuts. USDA ERS FTS 358SA:27.

You, F.M., K.R. Deal, J. Wang, M.T. Britton, J.N. Fass, D. Lin, A.M. Dandekar, C.A. Leslie, M Aradhya, M.C. Luo, and J. Dvorak. 2012. Genome-wide SNP discovery in walnut with an AGSNP pipeline updated for SNP discovery in allogamous organisms. BMC Genomics 13:354.

Zedan, D. 2015a. The 2014/2015 pecan market How did we get here and where are we headed?
Feb. 2015. <http://www.nffonline.com/sites/ default/files/2015\%20S.\%20African $\% 20$ Pecan $\%$ 20Assoc\%20Presentation.pdf $>$.

Zedan, D. 2015b. As pecan prices firm, the South African pecan industry prepares for the future. May 2015. <http://www.nffonline.com/industrynews/2015/03/06/pecan-prices-firm-south-africanpecan-industry-prepares-future $>$.

Zhang, B., Z.J. Wang, S.H. Jin, G.H. Xia, Y.J. Huang, and J.Q. Huang. 2012. A pattern of unique embryogenesis occurring via apomixis in Carya cathayensis. Biol. Plant. 56:620-627.

Zhang, J.B., R.Q. Li, X.G. Xiang, S.R. Manchester, L. Lin, W. Wang, J. Wen, and Z.D. Chen. 2013. Integrated fossil and molecular data reveal the biogeographic diversification of the Eastern AsianEastern North American disjunct hickory genus (Carya Nutt.). PLoS One8(7):e70449. 